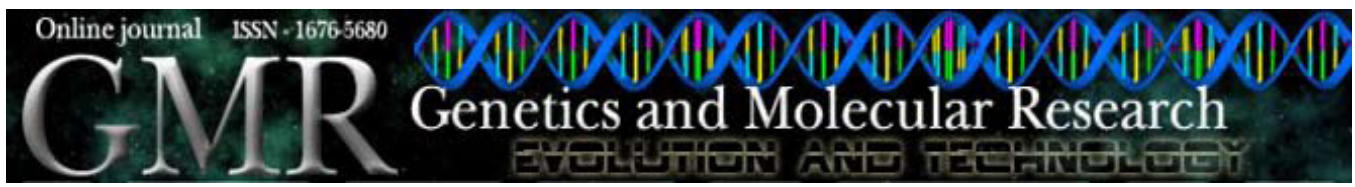

\title{
Complete mitochondrial genome of Cabot's tragopan, Tragopan caboti (Galliformes: Phasianidae)
}

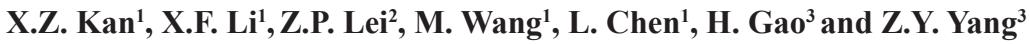 \\ ${ }^{1}$ The Provincial Key Laboratory of the Conservation and Exploitation Research \\ of Biological Resources in Anhui, College of Life Sciences, Anhui Normal \\ University, Wuhu, China \\ ${ }^{2}$ The Administration Bureau of Wuyanling National Nature Reserve, Taishun, \\ China \\ ${ }^{3}$ State Key Laboratory of Systematic and Evolutionary Botany, Institute of \\ Botany, Chinese Academy of Sciences, Beijing, China \\ Corresponding author: X.Z. Kan \\ E-mail: xianzhaokan@gmail.com
}

Genet. Mol. Res. 9 (2): 1204-1216 (2010)

Received February 25, 2010

Accepted March 29, 2010

Published June 22, 2010

DOI 10.4238/vol9-2gmr820

\begin{abstract}
Cabot's tragopan, Tragopan caboti, is a globally threatened pheasant endemic to southeast China. The complete mitochondrial genome of Cabot's tragopan was sequenced. The circular genome contains $16,727 \mathrm{bp}$, encoding a standard set of 13 protein-coding genes, two ribosomal RNA genes, and 22 transfer RNA genes, plus the putative control region, a structure very similar to that of other Galliformes. As found in other vertebrates, most of these genes code on the H-strand, except for the NADH dehydrogenase subunit 6 (nad6) and eight tRNA genes (Gln, Ala, Asn, Cys, Tyr, Ser(UCN), Pro, Glu). All protein-coding genes initiated with ATG, except for cox1, which began with GTG, and had a strong skew of C vs G (GC skew $=-0.29$ to -0.73 ). One extra ' $C$ ' nucleotide was found in the NADH dehydrogenase subunit 3 (nad3). All the tRNA gene sequences have the potential to fold into typical cloverleaf secondary structures. Conserved sequences in three domains were identified within the control region
\end{abstract}


(D-loop). These results provide basic information for phylogenetic analyses among Galliform birds, and especially Tragopan species.

Key words: Mitochondrial genome; Cabot's tragopan; Phasianidae; Tragopan caboti; Galliformes

\section{INTRODUCTION}

The living birds classified within the order Galliformes form a large and cosmopolitan group comprising more than 250 species within some 70 genera (Monroe and Sibley, 1990). Galliformes are traditionally classified into seven families: Megapodiidae (mound builders, brush turkeys, and allies), Cracidae (curassows, guans, and chachalacas), Odontophoridae (New World quails), Numididae (guineafowl), Phasianidae (pheasants, partridges, Old World quails, and allies), Meleagrididae (turkeys), and Tetraonidae (grouse and allies) (del Hoyo et al., 1994). Based on molecular markers and comprehensive taxon sampling, current classification suggested that the Meleagrididae should be classified into the Phasianidae (Dyke et al., 2003; Crowe et al., 2006; He et al., 2009). Tragopan is a genus of bird in the family Phasianidae. These birds are commonly called "horned pheasants" because of two brightly colored, fleshy horns on their heads that they can erect during courtship displays. There are five recognized species in Tragopan, namely T. melancephalus, T. satyra, T. temminckii, T. blythii, and T. caboti. Cabot's tragopan, T. caboti, is a globally threatened pheasant endemic to southeast China, where it is known as the Yellow-bellied tragopan (Zhang and Zheng, 2007). The typical habitats of the tragopan have been seriously fragmented because of forest management for timber production and farmland reclamation in recent years (Deng and Zheng, 2004). As a result it was classified as Vulnerable (VU) in the International Union for the Conservation of Nature and Natural Resources (IUCN) Red List (IUCN 2009), and also listed in the first category of National Key Protected Wild Animals in China.

Mitochondrial genomes have great potential for resolving ancient patterns of evolutionary history and for serving as a model of genome evolution. With a few exceptions, metazoan mitochondrial genomes are double-stranded, circular molecules, 15-20 kb in size, containing 37 genes: 13 protein-coding genes, 22 transfer RNA genes (tRNAs) and two ribosomal RNA genes (rRNAs) (Wolstenholme, 1992; Boore, 1999). The genome is highly economized with few sections of noncoding DNA, intergenic regions or repetitive sequences, except for one major control region. The control region is believed to control the initiation of replication and transcription of animal mitochondrial DNA (mtDNA) (Shadel and Clayton, 1997). Because of its compactness, maternal inheritance, fast evolutionary rate compared to nuclear DNA, and short coalescence time, mtDNA is useful for population genetic studies such as the analysis of gene flow, hybridization and introgression (Moore, 1995). Thus, the mitochondrial genome can provide abundant information for evolutionary studies of many taxa, and can also be used as a source of molecular markers in the conservation studies of endangered species (He et al., 2009; Zhang et al., 2009). To date, the complete mtDNA sequences are available for 21 Galliformes species (Table 1); however, no complete mitochondrial sequence has been reported for members of the genus Tragopan. In this study, we present the complete mitochondrial genome of T. caboti (Galliformes: Phasianidae) and give a thorough description of its genome features in comparison to other Galliformes species. 


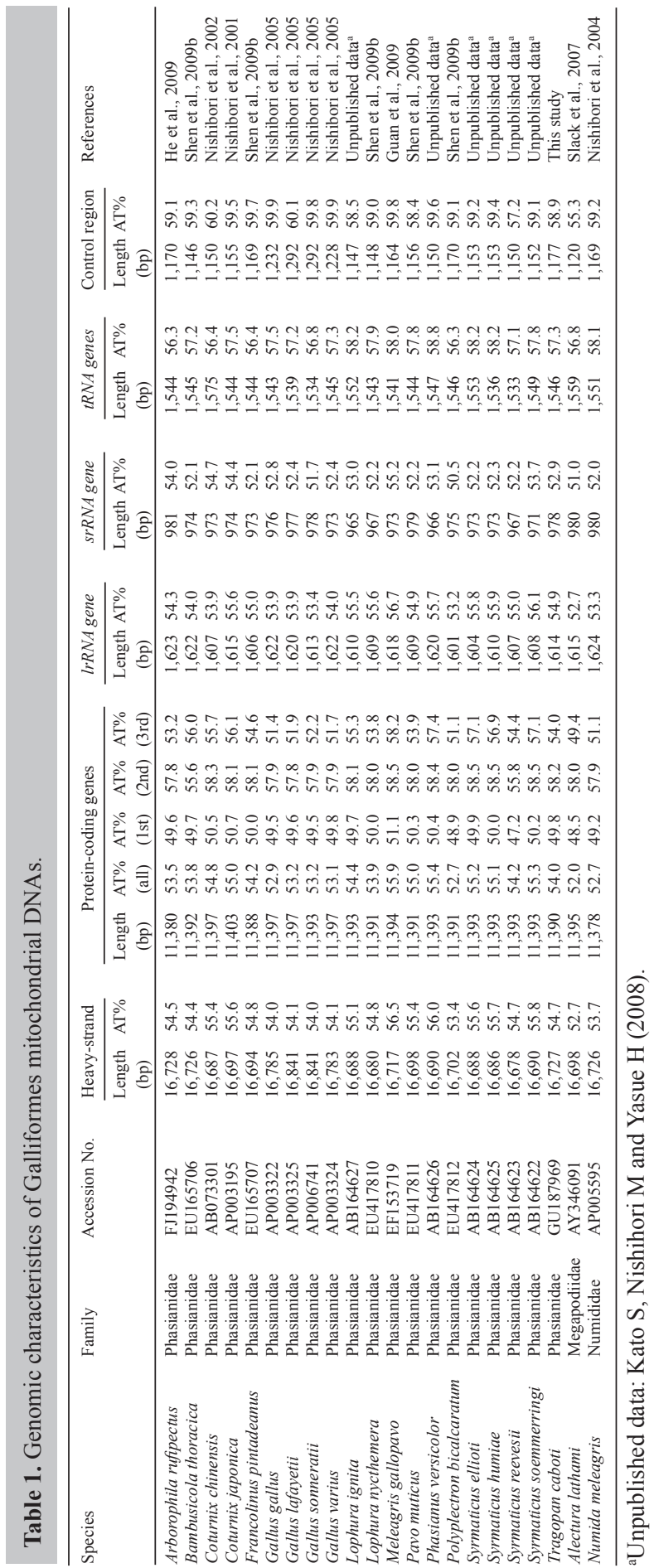




\section{MATERIAL AND METHODS}

\section{Sample collection and DNA extraction}

A naturally dead individual Cabot's tragopan (male) was obtained from the Wuyanling National Nature Reserve $\left(27^{\circ} 43^{\prime} \mathrm{N}, 119^{\circ} 39^{\prime} \mathrm{E}\right)$, Zhejiang Province, China. Total genomic DNA was extracted from the muscle tissue using the standard phenol/chloroform methods (Sambrook and Russell, 2001).

\section{PCR amplification and sequencing}

To minimize the possibility of obtaining nuclear copies of mitochondrial genes (NUMTs), two long overlapping fragments ( $\sim 16 \mathrm{~kb}$ in length) were first amplified using the long and accurate-polymerase chain reaction (LA-PCR) kit (Takara, Dalian, China). The first LA-PCR primer set was LA16SF and LA16SR of Nishibori et al. (2001). The second primer set was CytbF605 and CytbR252, designed based on the sequence of Cytochrome b gene $(\mathrm{cob})$ from Cabot's tragopan. The LA-PCR was conducted at $94^{\circ} \mathrm{C}$ for $1 \mathrm{~min}$, followed by 35 cycles consisting of $10 \mathrm{~s}$ denaturation at $98^{\circ} \mathrm{C}$ and a $15-\mathrm{min}$ annealing and extension at $68^{\circ} \mathrm{C}$, with a final extension step of $10 \mathrm{~min}$ at $72^{\circ} \mathrm{C}$, using a DNA Thermal Cycler TC-3000 (Techne, Barloworld Scientific Ltd., UK). The amplified fragments with a size of approximately $16 \mathrm{~kb}$ thus obtained were used as the templates for the short overlapping fragment (1.1-1.5 kb in length) amplification with 15 primer sets (Table 2). All the 15 sets of primers were designed based on the conserved sequences of mitochondrial genome among other species of Galliformes, which were aligned using CLUSTAL X, version 2.0.10 (Larkin et al., 2007). Each primer set amplified an mtDNA fragment containing an overlap of at least $100 \mathrm{bp}$ with the adjacent amplified fragment at both termini. PCR was carried out in a volume of $25 \mu \mathrm{L}$ containing 5-50 ng DNA template, 6.25 pmol of each primer, $0.2 \mathrm{mM}$ of each dNTP, $2 \mathrm{mM} \mathrm{MgCl}$, and $0.625 \mathrm{U}_{\text {DreamTa }}{ }^{\mathrm{TM}}$ DNA polymerase (Fermentas, Burlington, Canada). Amplification was conducted in the DNA Thermal Cycler TC-3000 as above. PCR cycles were as follows: one cycle of $4 \mathrm{~min}$ at $70^{\circ} \mathrm{C}, 4$ cycles of $40 \mathrm{~s}$ at $94^{\circ} \mathrm{C}, 20 \mathrm{~s}$ at $52^{\circ} \mathrm{C}$, and $2 \mathrm{~min}$ and $10 \mathrm{~s}$ at $72^{\circ} \mathrm{C}$, followed by 36 cycles of $20 \mathrm{~s}$ at $94^{\circ} \mathrm{C}, 20 \mathrm{~s}$ at $50-55^{\circ} \mathrm{C}$, and $2 \mathrm{~min}$ and $10 \mathrm{~s}$ at $72^{\circ} \mathrm{C}$. The process was completed with a final elongation at $72^{\circ} \mathrm{C}$ for $10 \mathrm{~min}$. The band with the right size was cut out and purified using an EZ Spin Column DNA Gel Extraction Kit (Bio Basic Inc.). The purified PCR products were sequenced directly on an ABI-PRISM 3730 sequencer using a BigDye Terminator, version 3.1, Cycle Sequencing Kit (Applied Biosystems) and the corresponding primer.

\section{Gene identification and genome analyses}

DNA sequences were analyzed using the DNASTAR Lasergene, version 5.0, software. Contig assembly was performed with the ContigExpress program (a component of Vector NTI Suite 6.0). The boundaries of protein-coding genes and rRNA genes were initially identified via DOGMA (Wyman et al., 2004) using the default setting, and refined by alignment with mitochondrial genomes of other species of Galliformes. Most tRNA genes were identified using tRNAscan-SE 1.21 (Lowe and Eddy, 1997) under the 'cove only' search mode, with the vertebrate mitochondrial genetic code and 'mito/chloroplast' source. Some tRNA genes, 


\begin{tabular}{|c|c|c|c|c|}
\hline No. of primer pair & Name & Sequences $\left(5^{\prime}-3^{\prime}\right)$ & Size (bp) & Sources \\
\hline \multirow[t]{2}{*}{1} & LA16SF & CCTACGTGATCTGAGTTCAGACCGGAGCAATCCAG & 35 & Nishibori et al., 2001 \\
\hline & LA16SR & TGCACCATTAGGTTGTCCTGATCCAACATCGAGGT & 35 & Nishibori et al., 2001 \\
\hline \multirow[t]{2}{*}{2} & CytbF605 & ATGAATCAGGCTCTAACAACCCTCTGGGCATC & 32 & This study \\
\hline & CytbR252 & GATGCAGATGAAGAAGAATGAGGCGCCGTTTGC & 33 & This study \\
\hline \multirow[t]{2}{*}{3} & AVMT1F & GCCAAATAGCATCCTTCTCC & 20 & This study \\
\hline & AVMT1R & GAGGTGGACGATCAATAAAT & 20 & This study \\
\hline \multirow[t]{2}{*}{4} & AVMT2F & AACCCATTATATGTATACGG & 20 & This study \\
\hline & AVMT2R & TTACTGCTGAGTACCCGTGG & 20 & This study \\
\hline \multirow[t]{2}{*}{5} & AVMT3F & GCAAAAGACTTAGTCCTAACC & 21 & This study \\
\hline & AVMT3R & CTTTTGCGACAGAGACGGGTT & 21 & This study \\
\hline \multirow[t]{2}{*}{6} & AVMT4F & AAGTCGTAACAAGGTAAGTGAC & 22 & This study \\
\hline & AVMT4R & CGCCCCAACCGAAAAATGTC & 20 & This study \\
\hline \multirow[t]{2}{*}{7} & AVMT5F & AAGACGAGAAGACCCTGTGG & 20 & This study \\
\hline & AVMT5R & AGCTCTGACTCTCCTTCTGT & 20 & This study \\
\hline \multirow[t]{2}{*}{8} & AVMT6F & TAAGCACCCTGGCCATCACC & 20 & This study \\
\hline & AVMT6R & ATGAGATGAGTATTGTTGAT & 20 & This study \\
\hline \multirow[t]{2}{*}{9} & AVMT7F & ACACAGACACGAAAAATCCT & 20 & This study \\
\hline & AVMT7R & GTGATAAAGTTGATGGCTCCT & 21 & This study \\
\hline \multirow[t]{2}{*}{10} & AVMT8F & CGCATAAATAACATAAGCTTC & 21 & This study \\
\hline & AVMT8R & GAAGCATTAAGTGGTTTGAT & 20 & This study \\
\hline \multirow[t]{2}{*}{11} & AVMT9F & AAGCCTTCTCAGCAAAACGA & 20 & This study \\
\hline & AVMT9R & GCTTAGGTTCATGGTCAGGT & 20 & This study \\
\hline \multirow[t]{2}{*}{12} & AVMT10F & ATGACATGCCCCAATTAAACC & 21 & This study \\
\hline & AVMT10R & GATGGCTTGTTTTCGGTTTCC & 21 & This study \\
\hline \multirow[t]{2}{*}{13} & AVMT11F & CAAGCCTAGCCCCAACACCAG & 21 & This study \\
\hline & AVMT11R & ATGGGGTTAGTCAGTGTAGGC & 21 & This study \\
\hline \multirow[t]{2}{*}{14} & AVMT12F & CTCTGACCACCTACACAACCT & 21 & This study \\
\hline & AVMT12R & AGTAGTATGTAGAGGGTGT & 19 & This study \\
\hline \multirow[t]{2}{*}{15} & AVMT13F & ACTACGAACGGACACACAGCCG & 22 & This study \\
\hline & AVMT13R & GAAGGCCAAATTGAGCGGAT & 20 & This study \\
\hline \multirow[t]{2}{*}{16} & AVMT14F & ATGACAAGGACGAGCTTAAG & 20 & This study \\
\hline & AVMT14R & ATTATTTTTAGTAGGGGGTG & 20 & This study \\
\hline \multirow[t]{2}{*}{17} & AVMT15F & GCCAACCTTCATCTCACCATAA & 22 & This study \\
\hline & AVMT15R & CTTGTGCGTGGGTTGTCTCGGG & 22 & This study \\
\hline
\end{tabular}

which were not found by the tRNA-SE1.21, were identified by proposed secondary structures and anti-codons (Kumazawa and Nishida, 1993; He et al., 2009; Shen et al., 2009a). Gene map of the mitochondrial genome of $T$. caboti was initially generated with OGDRAW (Lohse et al., 2007) and modified manually

\section{RESULTS AND DISCUSSION}

\section{Genome composition}

The complete sequence of the mtDNA of $T$. caboti is $16,727 \mathrm{bp}$ in length (Figure 1 and Table 1) and was deposited in GenBank with the accession number (GU187969). The size of the Galliformes mtDNA ranges from 16,678 bp (Syrmaticus reevesii) to 16,841 bp (Gallus lafayettii and $G$. sonneratii). Similar to the typical mitochondrial genomes of vertebrates, the Cabot's tragopan mtDNA consists of 13 typical protein-coding genes, 22 transfer RNA genes, 2 ribosomal RNA genes ( $s r R N A$ and $l r R N A$ ), and one putative control region (D-loop) (Table $3)$. As found in other vertebrates, most of these genes were coded on the H-strand, except for one protein-coding gene (nad6) and eight tRNA genes ( $t R N A^{G l n}, t R N A^{4 l a}, t R N A^{A s n}, t R N A^{C y s}$, $\left.t R N A^{T y r}, t R N A^{\operatorname{Ser}(U C N)}, t R N A^{P r o}, t R N A^{\text {Glu }}\right)$. 


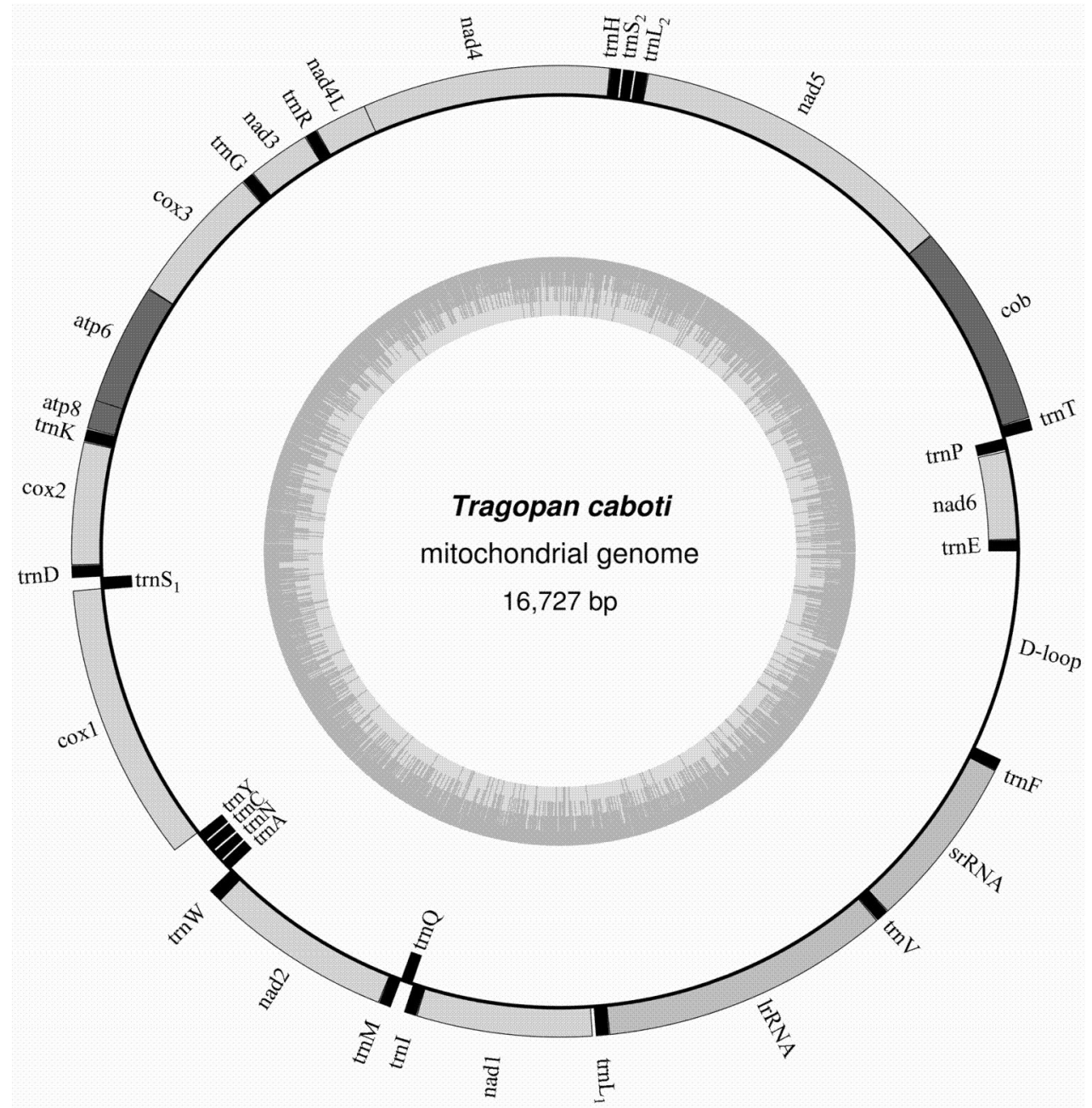

Figure 1. Gene map of the mitochondrial genome of Tragopan caboti. Genes encoded on the heavy or light strands are shown outside or inside the circular gene map, respectively. The inner ring displays the GC content. Twenty-two tRNA genes are designated by single-letter amino acid codes. The figure was initially generated with OGDRAW and modified manually.

The overall base composition of $\mathrm{H}$-strand is as follows: A (30.4\%), $\mathrm{T}(24.3 \%), \mathrm{G}$ (13.7\%), C (31.6\%), and the A+T content of T. caboti (54.7\%) is similar to those of other Galliformes (ranging from 52.7 to $56.5 \%$ ) (Table 1). As in most vertebrates, the overall base composition is skewed against guanine in the T. caboti mt genome, which is due to a strong bias against the use of guanine at the third codon position (San Mauro et al., 2004).

Furthermore, one extra nucleotide ' $\mathrm{C}$ ' is present in nad 3 of $T$. caboti, which is consistently observed in Galliformes except for Arborophila rufipectus (He et al., 2009). This extra nucleotide is found in many other birds and some turtles and is thought not to be translated (Mindell et al., 1998; Slack et al., 2003). We found 82 species present in the extra nucleotide of nad 3 within all currently available 107 avian mitochondrial genome sequences retrieved from 
Table 3. Localization and features of genes in the mitochondrial genome of Tragopan caboti.

\begin{tabular}{|c|c|c|c|c|c|c|c|c|c|}
\hline \multirow{2}{*}{ Gene/region } & \multirow[t]{2}{*}{ Strand } & \multicolumn{2}{|c|}{ Position } & \multicolumn{2}{|c|}{ Size (bp) } & \multicolumn{2}{|c|}{ Codon } & \multirow[t]{2}{*}{ Anticodon } & \multirow{2}{*}{$\begin{array}{c}\text { Intergenic } \\
\text { nucleotides }{ }^{b}\end{array}$} \\
\hline & & From & To & Nucleotide & Amino acid & Start & $\overline{\text { Stop }^{a}}$ & & \\
\hline D-loop & $\mathrm{H}$ & 1 & 1,177 & 1,177 & & & & & 0 \\
\hline tRNA Phe & $\mathrm{H}$ & 1,178 & 1,245 & 68 & & & & GAA & -1 \\
\hline SrRNA & $\mathrm{H}$ & 1,245 & 2,222 & 978 & & & & & 0 \\
\hline$t R N A^{v a l}$ & $\mathrm{H}$ & 2,223 & 2,295 & 73 & & & & TAC & 1 \\
\hline $\operatorname{lr} R N A$ & $\mathrm{H}$ & 2,297 & 3,910 & 1,614 & & & & & 0 \\
\hline$t R N A^{\text {Leu(UUR) }}$ & $\mathrm{H}$ & 3,911 & 3,984 & 74 & & & & TAA & 16 \\
\hline nadl & $\mathrm{H}$ & 4,001 & 4,975 & 975 & 324 & ATG & TAA & & 0 \\
\hline$t R N A^{H e}$ & $\mathrm{H}$ & 4,976 & 5,046 & 71 & & & & GAT & 6 \\
\hline$t R N A^{G / n}$ & L & 5,053 & 5,123 & 71 & & & & TTG & -1 \\
\hline$t R N A^{M e t}$ & $\mathrm{H}$ & 5,123 & 5,191 & 69 & & & & CAT & 0 \\
\hline nad 2 & $\mathrm{H}$ & 5,192 & 6,230 & 1,039 & 346 & ATG & $\mathrm{T}-$ & & 0 \\
\hline$t R N A^{T p}$ & $\mathrm{H}$ & 6,231 & 6,308 & 78 & & & & $\mathrm{TCA}$ & 5 \\
\hline tRNA & L & 6,314 & 6,382 & 69 & & & & $\mathrm{TGC}$ & 3 \\
\hline$t R N A^{A s n}$ & $\mathrm{~L}$ & 6,386 & 6,458 & 75 & & & & GTT & 2 \\
\hline$t R N A^{C_{y s}}$ & $\mathrm{~L}$ & 6,461 & 6,526 & 67 & & & & GCA & -1 \\
\hline$t R N A^{T y r}$ & $\mathrm{~L}$ & 6,526 & 6,596 & 71 & & & & GTA & 1 \\
\hline coxl & $\mathrm{H}$ & 6,598 & 8,148 & 1,551 & 516 & GTG & AGG & & -9 \\
\hline$t R N A^{\operatorname{Ser}(U C N)}$ & L & 8,140 & 8,214 & 75 & & & & TGA & 2 \\
\hline$t R N A^{A s p}$ & $\mathrm{H}$ & 8,217 & 8,285 & 69 & & & & GTC & 1 \\
\hline $\cos 2$ & $\mathrm{H}$ & 8,287 & 8,970 & 684 & 227 & ATG & TAA & & 1 \\
\hline$t R N A^{L y s}$ & $\mathrm{H}$ & 8,972 & 9,041 & 70 & & & & TTT & 2 \\
\hline atp8 & $\mathrm{H}$ & 9,044 & 9,208 & 165 & 54 & ATG & TAA & & -10 \\
\hline atp6 & $\mathrm{H}$ & 9,199 & 9,882 & 684 & 227 & ATG & TAA & & -1 \\
\hline $\cos 3$ & $\mathrm{H}$ & 9,882 & 10,665 & 784 & 261 & ATG & T- & & 0 \\
\hline tRNA & $\mathrm{H}$ & 10,666 & 10,734 & 69 & & & & $\mathrm{TCC}$ & 0 \\
\hline nad 3 & $\mathrm{H}$ & 10,735 & 11,085 & 351 & & ATG & TA- & & 0 \\
\hline tRNA $A^{A r g}$ & $\mathrm{H}$ & 11,086 & 11,154 & 69 & & & & TCG & 0 \\
\hline $\operatorname{nad} 4 L$ & $\mathrm{H}$ & 11,155 & 11,451 & 297 & 98 & ATG & TAA & & -7 \\
\hline nad4 & $\mathrm{H}$ & 11,445 & 12,822 & 1,378 & 459 & ATG & $\mathrm{T}-$ & & 0 \\
\hline$t R N A^{H i s}$ & $\mathrm{H}$ & 12,823 & 12,891 & 69 & & & & GTG & 1 \\
\hline$t R N A^{\operatorname{Ser}(A G Y)}$ & $\mathrm{H}$ & 12,893 & 12,957 & 65 & & & & GCT & 1 \\
\hline$t R N A^{\operatorname{Leu}(C U N)}$ & $\mathrm{H}$ & 12,959 & 13,029 & 71 & & & & TAG & 0 \\
\hline nad 5 & $\mathrm{H}$ & 13,030 & 14,844 & 1,815 & 604 & ATG & TAA & & -1 \\
\hline$c o b$ & $\mathrm{H}$ & 14,844 & 15,986 & 1,143 & 380 & ATG & TAG & & 2 \\
\hline$t R N A^{T h r}$ & $\mathrm{H}$ & 15,989 & 16,057 & 69 & & & & TGT & 2 \\
\hline$t R N A^{P r o}$ & L & 16,060 & 16,129 & 70 & & & & TGG & 6 \\
\hline nad6 & $\mathrm{L}$ & 16,136 & 16,657 & 522 & 173 & ATG & TAG & & 1 \\
\hline tRNA $A^{\text {Glu }}$ & $\mathrm{L}$ & 16,659 & 16,727 & 69 & & & & TTC & 0 \\
\hline
\end{tabular}

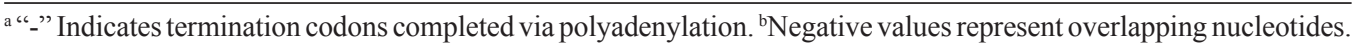

GenBank (data not shown). However, the extra ' $\mathrm{C}$ ' of nad3 was not observed in all available nine mtDNA sequences from Passeriformes. Although Russell and Beckenbach (2008) put forward a hypotheses that certain mitochondrial translation systems have the ability to tolerate frameshift insertions using programmed translational frameshifting, the function of the extra "C" in nad 3 and its phylogenetic implications are still unclear.

\section{Protein-coding genes: nucleotide composition and codon usage}

As shown in Table 1, the total length of the 13 protein-coding genes (PCGs) in $T$. caboti mtDNA is $11,390 \mathrm{bp}$, accounting for $68.1 \%$ of the complete mitogenome. The length of 13 PCGs found in the Galliformes species varies from $11,378 \mathrm{bp}$ (Numida meleagris) to 11,403 bp (Coturnix japonica). The 13 PCGs found in the T. caboti mtDNA are similar in length to most other Galliformes species. The longest PCG of T. caboti mtDNA is the nad5 gene (1815 bp), whereas the shortest is atp 8 gene (165 bp) (Table 4). 


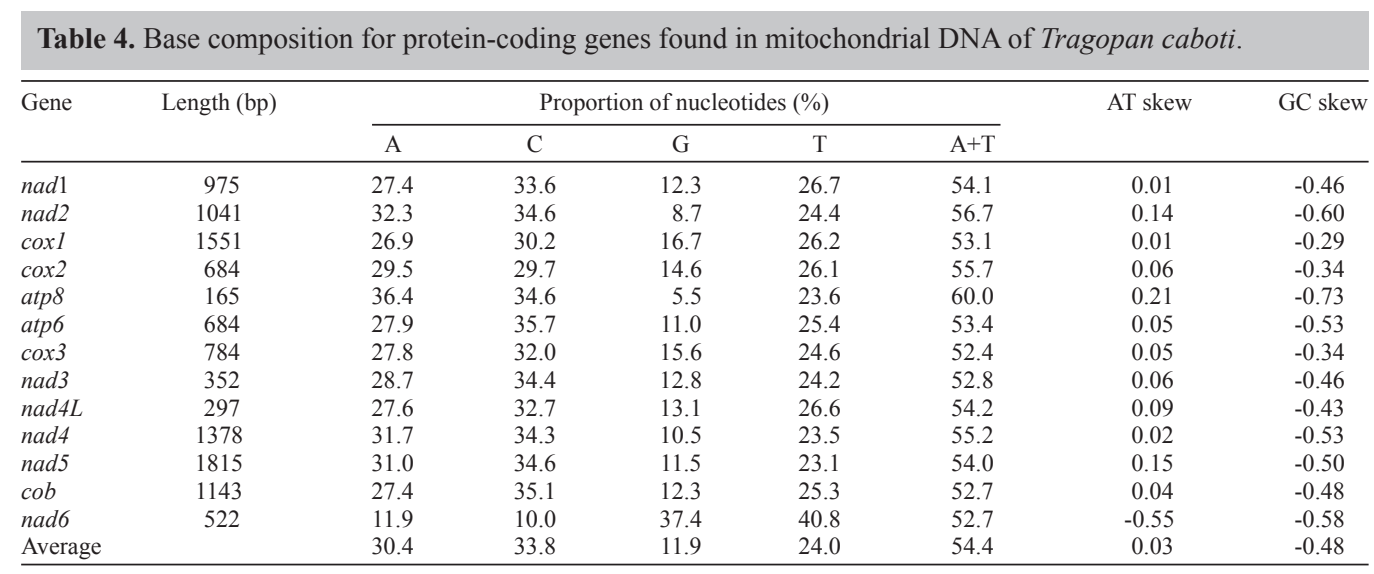

The AT composition at the first codon position is $49.8 \%$. The values of the second and third codon positions are 58.2 and $54.0 \%$, respectively (Table 1). As with most Galliformes species (except for Bambusicola thoracica), the AT composition of the second codon position is the highest (Table 1). The bias of the base composition in each protein-coding gene can be described by skewness (Perna and Kocher, 1995), which measures the relative numbers of As to Ts and Gs to Cs, and is calculated as $(\mathrm{A} \%-\mathrm{T} \%) /(\mathrm{A} \%+\mathrm{T} \%)$ and $(\mathrm{G} \%-\mathrm{C} \%) /(\mathrm{G} \%+\mathrm{C} \%)$, respectively. Twelve PCGs of $T$. caboti mitochondrial genome (with the exception of nad6) have a slight skew of A vs T (AT skew $=0.01$ to 0.55$)$, and a strong skew of $\mathrm{C} v \mathrm{G}(\mathrm{GC}$ skew $=-0.29$ to -0.73$)$ (Table 4).

Within the mitochondrial genome of $T$. caboti, there are 3 reading frame overlaps (cox1 and $t R N A^{\text {ser }(U C N)}$ share 9 nucleotides; atp 8 and atp6 share 10 nucleotides; nad $4 L$ and nad4 share 7 nucleotides). Other overlaps are shown in Table 3.

Of the 13 typical PCGs (nad1-6 and 4L, cox1-3, atp6 and atp8, cob), 12 genes (with the exception of nad6) are encoded on the heavy strand. All PCGs initiate with ATG, except for $\operatorname{cox} 1$, which begins with GTG. Four types of stop codons were used by the coding genes, including TAA for nad1, cox2, atp8, atp6, nad4L, and nad5; TAG for cob and nad6; AGG for coxl, and incomplete stop codon T- or TA- for nad2, nad3, $\operatorname{cox} 3$, and nad4, respectively. The use of an incomplete stop codon T- as a common mechanism for stopping protein translations was also observed in other avian species.

The pattern of codon usage in the T. caboti mtDNA was also studied (Table 5). There are 3785 codons for all the 13 protein-coding genes after stop codons are excluded. The most frequently used amino acid was Leu (17.39\%), followed by Thr $(9.36 \%)$, Ile $(8.09 \%)$, Ser (7.77\%), and Ala (7.56\%).

\section{Non-coding regions}

A total of 17 intergenic sequences, ranging in size from 1 to $1177 \mathrm{bp}$, were found in the mitochondrial genome of T. caboti (Table 1). Among these, the longest non-coding region (1177 bp) was found between $t R N A^{G l u}$ and $t R N A^{\text {Phe }}$ genes. The length of control region of Galliformes species varied between 1120 bp (Alectura lathami) and 1292 bp (Gallus lafayettei and G. sonneratii), and ranging in AT content from $55.3 \%$ (A. lathami) to $60.2 \%$ (C. chinensis) (Table 1 ). Based on the distribution of the variable nucleotide positions and differential frequencies 
Table 5. Codon usage of 13 protein-coding genes in the mitochondrial genome of Tragopan caboti.

\begin{tabular}{|c|c|c|c|c|c|c|c|}
\hline $\begin{array}{l}\text { Amino } \\
\text { acid }\end{array}$ & Codon & Number & $\begin{array}{c}\text { Frequency } \\
(\%)\end{array}$ & $\begin{array}{l}\text { Amino } \\
\text { acid }\end{array}$ & Codon & Number & $\begin{array}{c}\text { Frequency } \\
(\%)\end{array}$ \\
\hline \multirow[t]{2}{*}{ Phe } & TTT & 74 & 1.95 & \multirow[t]{2}{*}{ Tyr } & TAT & 41 & 1.08 \\
\hline & TTC & 141 & 3.71 & & TAC & 64 & 1.69 \\
\hline \multirow[t]{6}{*}{ Leu } & TTA & 69 & 1.82 & \multirow[t]{2}{*}{ Stop } & TAA & 7 & 0.18 \\
\hline & TTG & 23 & 0.61 & & TAG & 3 & 0.08 \\
\hline & CTT & 72 & 1.90 & \multirow[t]{2}{*}{ His } & CAT & 27 & 0.71 \\
\hline & CTC & 191 & 5.03 & & $\mathrm{CAC}$ & 87 & 2.29 \\
\hline & CTA & 257 & 6.77 & \multirow[t]{2}{*}{ Gln } & CAA & 84 & 2.21 \\
\hline & CTG & 48 & 1.26 & & $\mathrm{CAG}$ & 10 & 0.26 \\
\hline \multirow[t]{2}{*}{ Ile } & ATT & 86 & 2.27 & \multirow[t]{2}{*}{ Asn } & AAT & 28 & 0.74 \\
\hline & ATC & 221 & 5.82 & & $\mathrm{AAC}$ & 100 & 2.63 \\
\hline \multirow[t]{2}{*}{ Met } & ATA & 131 & 3.45 & \multirow[t]{2}{*}{ Lys } & AAA & 80 & 2.11 \\
\hline & ATG & 35 & 0.92 & & AAG & 9 & 0.24 \\
\hline \multirow[t]{4}{*}{ Val } & GTT & 33 & 0.87 & \multirow[t]{2}{*}{ Asp } & GAT & 18 & 0.47 \\
\hline & GTC & 43 & 1.13 & & GAC & 45 & 1.19 \\
\hline & GTA & 67 & 1.77 & \multirow[t]{2}{*}{ Glu } & GAA & 83 & 2.19 \\
\hline & GTG & 23 & 0.61 & & GAG & 12 & 0.32 \\
\hline \multirow[t]{4}{*}{ Ser } & $\mathrm{TCT}$ & 43 & 1.13 & \multirow[t]{2}{*}{ Cys } & TGT & 4 & 0.11 \\
\hline & $\mathrm{TCC}$ & 79 & 2.08 & & $\mathrm{TGC}$ & 21 & 0.55 \\
\hline & TCA & 110 & 2.90 & \multirow[t]{2}{*}{$\operatorname{Trp}$} & TGA & 93 & 2.45 \\
\hline & $\mathrm{TCG}$ & 6 & 0.16 & & TGG & 16 & 0.42 \\
\hline \multirow[t]{4}{*}{ Pro } & $\mathrm{CCT}$ & 31 & 0.82 & \multirow[t]{4}{*}{ Arg } & CGT & 5 & 0.13 \\
\hline & $\mathrm{CCC}$ & 84 & 2.21 & & $\mathrm{CGC}$ & 16 & 0.42 \\
\hline & $\mathrm{CCA}$ & 104 & 2.74 & & CGA & 41 & 1.08 \\
\hline & $\mathrm{CCG}$ & 9 & 0.24 & & CGG & 8 & 0.21 \\
\hline \multirow{4}{*}{ Thr } & ACT & 60 & 1.58 & \multirow[t]{4}{*}{ Ser } & AGT & 14 & 0.37 \\
\hline & $\mathrm{ACC}$ & 154 & 4.06 & & AGC & 42 & 1.10 \\
\hline & ACA & 138 & 3.64 & & AGA & 0 & 0 \\
\hline & ACG & 3 & 0.08 & & $\mathrm{AGG}$ & 1 & 0.03 \\
\hline \multirow[t]{4}{*}{ Ala } & GCT & 49 & 1.29 & \multirow[t]{4}{*}{ Gly } & GGT & 19 & 0.50 \\
\hline & GCC & 132 & 3.48 & & GGC & 81 & 2.13 \\
\hline & GCA & 95 & 2.50 & & GGA & 87 & 2.29 \\
\hline & GCG & 11 & 0.29 & & GGG & 28 & 0.74 \\
\hline
\end{tabular}

of the nucleotides, the mitochondrial control region is divided into three domains (Brown et al., 1986; Saccone et al., 1991; Randi and Lucchini, 1998). The nucleotide composition of the T. caboti control region was $\mathrm{A}=27.36 \%, \mathrm{~T}=31.52 \%, \mathrm{C}=27.02 \%$, and $\mathrm{G}=14.10 \%$, with a bias against $\mathrm{G}$, which is usual for the mtDNA sense strand of vertebrates (Wolstenholme, 1992) (Table 6). The domain I (ETAS, extended termination-associated sequences) contains part A (nt 1-163 in Figure 2) and part B (nt 164-315 in Figure 2). The first conserved block (5'-TACCCCCCCTTTCCCCCCCAGGGGGGGTA-3') in part A has sequence similarity to the "goose hairpin" as described in Anas caerulescens by Quinn (1992) (Figure 2). Furthermore, in part A, ETAS1 and ETAS2 are found in positions 64-126 and 124-163 nt, respectively, and overlapped one another by $3 \mathrm{bp}$, with 67.5 and $44.3 \%$ similarity to the consensus mammalian

Table 6. The nucleotide composition of the mitochondrial DNA control region of Tragopan caboti.

\begin{tabular}{|c|c|c|c|c|c|c|}
\hline \multirow[t]{2}{*}{ Region } & \multicolumn{2}{|c|}{ Position } & \multicolumn{4}{|c|}{ Nucleotide frequency $(\%)^{\mathrm{a}}$} \\
\hline & From & To & $\mathrm{A}$ & $\mathrm{C}$ & $\mathrm{G}$ & $\mathrm{T}$ \\
\hline Domain I & 1 & 315 & $31.43(29.52)$ & $28.25(31.39)$ & $12.70(14.78)$ & $27.62(24.30)$ \\
\hline Domain II & 316 & 783 & $16.45(20.38)$ & $29.27(29.07)$ & $20.94(19.34)$ & $33.33(31.22)$ \\
\hline Domain III & 784 & 1177 & $37.06(35.49)$ & $23.35(26.18)$ & $7.11(7.71)$ & $32.49(30.62)$ \\
\hline Complete CR & 1 & 1177 & $27.36(28.46)$ & $27.02(28.88)$ & $14.10(13.94)$ & $31.52(28.71)$ \\
\hline
\end{tabular}

${ }^{a}$ The numbers in parentheses indicate the nucleotide frequency of the average avian control region (CR) sequences (Ruokonen and Kvist, 2002). 
ETAS1 and ETAS2 (Sbisa et al., 1997). In part B (nt 164-315), a conserved sequence block 1 (CSB1)-like block (5'-TAACTATGAATGGTTACAGGACATA-3') has $73.1 \%$ similarity to the CSB1 in domain III (Figure 2). Four conserved sequence boxes in the central domain II (nt 316-783) were identified as boxes C, D, E, F (Figure 2). In domain III (nt 784-1177), a poly(C) sequence (nt 783-796), similar to the $\mathrm{O}_{\mathrm{H}}$ (origin of H-strand replication) of mammals, maps just a few nucleotides downstream from the putative CSB1 (nt 807-832) (Figure 2). The CSB domain of $T$. caboti has no obvious tracks of CSB2 and CSB3 (Walberg and Clayton, 1981). The bidirectional light- and heavy-strand transcription promoters (LSP/HSP) (L'Abbe et al., 1991) are found in T. caboti (Figure 2).

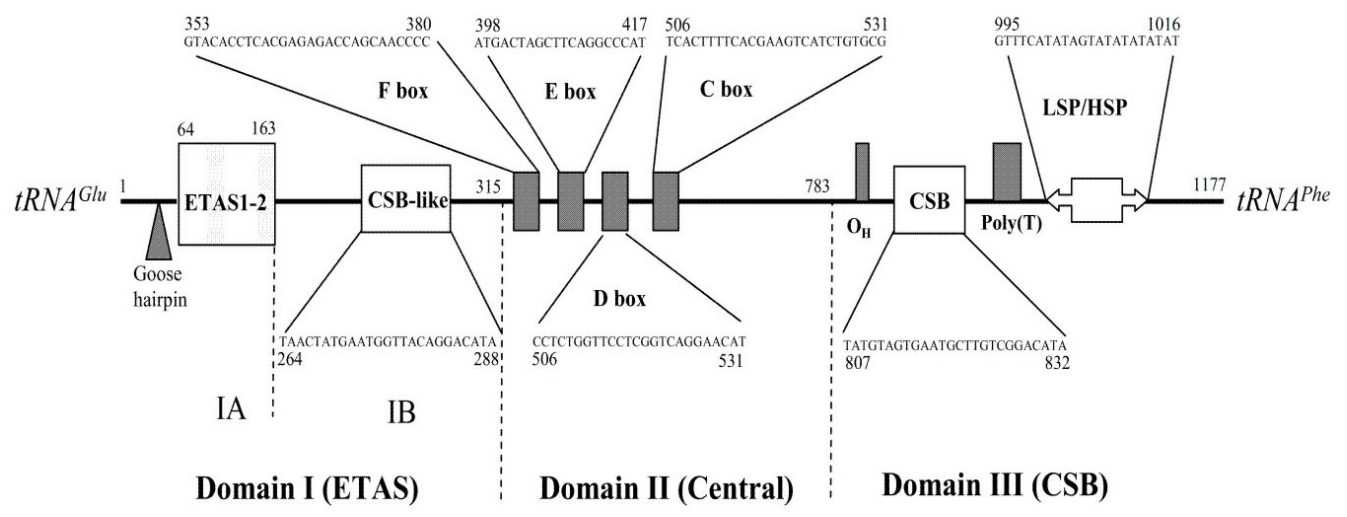

Figure 2. Schematic representation of the organization of the Tragopan caboti control region. ETAS = extended termination-associated sequences; $\mathrm{F}$ through $\mathrm{C}$ boxes $=$ conserved sequence boxes in the central domain; $\mathrm{O}_{\mathrm{H}}=$ origin of $\mathrm{H}$-strand replication; $\mathrm{CSB}=$ conserved sequence block; $\mathrm{CSB}-$ like $=$ a sequence similar to the CSB; $\mathrm{LSP}=$ light-strand transcription promoter; $\mathrm{HSP}=$ heavy-strand transcription promoter.

\section{Ribosomal and transfer RNA genes}

As in all other mt genomes sequenced so far, rRNA genes of $T$. caboti include small subunit rRNA ( $\operatorname{sr} R N A)$ and large subunit rRNA ( $\operatorname{lr} R N A)$. The $\operatorname{sr} R N A$ gene is located between $t R N A^{\text {Phe }}$ and $t R N A^{\text {Val }}$ genes, and the $\operatorname{lr} R N A$ gene is located between $t R N A^{\text {Val }}$ and $t R N A^{\text {Leu (UUR) }}$ genes. The lengths of srRNA and lrRNA are 978 and $1546 \mathrm{bp}$, and A+T content are 52.9 and 54.9\%, respectively, which are within the range observed in other Galliformes species (Table 1).

The complete mitochondrial sequence contains 22 tRNA genes, which are interspersed in the genome and range in size from $65\left(t R N A^{\operatorname{Ser}(A G Y)}\right)$ to $78\left(t R N A^{T r p}\right)$ nucleotides (Table 3). $t R N A^{L y s}$ and $t R N A^{\operatorname{Ser}(A G Y)}$, which were not found by the tRNAscan-SE, were identified by comparison with G. gallus counterparts. All the tRNA gene sequences have the potential to fold into typical cloverleaf secondary structures (Figure 3). The DHU arm contains 3-4 nucleotide pairs, and the $\mathrm{T} \Psi \mathrm{C}$ arm contains 3-5 nucleotide pairs.

This is the first complete nucleotide sequences for the mitochondrial genome of Cabot's tragopan Tragopan caboti distributed in the Wuyanling National Nature Reserve, China. We also reported the genome organization and codon usage of $T$. caboti mitochondrial DNA. These results will provide basic information for phylogenetic analyses among the Galliformes birds, and especially the Tragopan species. 

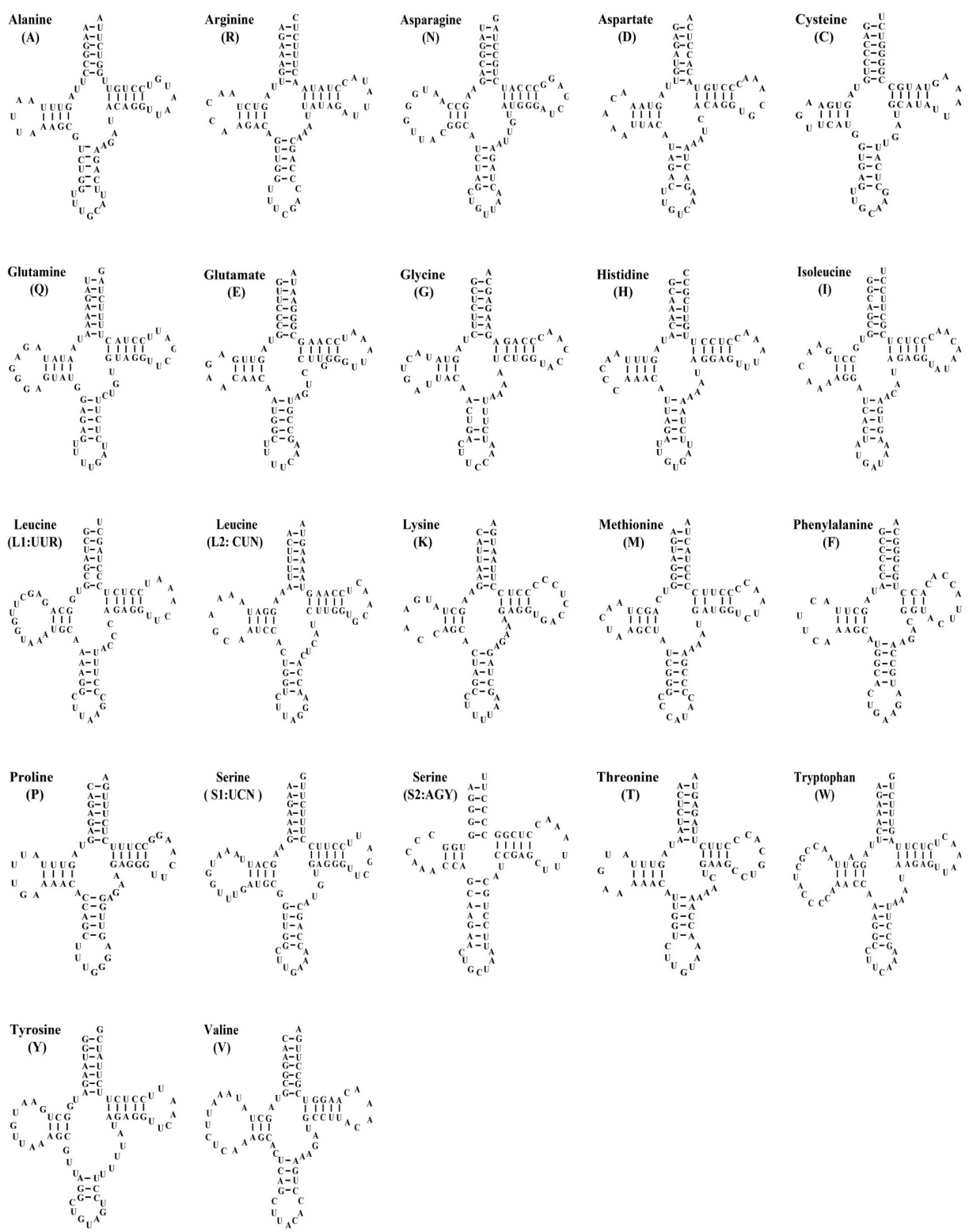

Figure 3. Inferred secondary structures of 22 tRNAs found in Tragopan caboti mtDNA.

\section{ACKNOWLEDGMENTS}

Research supported by the National Natural Science Foundation of China (\#30870172), the State Key Laboratory of Systematic and Evolutionary Botany, China (2009), the Key Program of Natural Science Foundation of the Anhui Higher Education Institutions 
(\#KJ2008A13ZC), the Natural Science Foundation of Anhui Normal University (\#2008xzx14), the Key Lab. of Biotic Environment and Ecology Safety in Anhui Province, and the Program for Innovative Research Team in Anhui Normal University.

\section{REFERENCES}

Boore JL (1999). Animal mitochondrial genomes. Nucleic Acids Res. 27: 1767-1780.

Brown GG, Gadaleta G, Pepe G, Saccone C, et al. (1986). Structural conservation and variation in the D-loop-containing region of vertebrate mitochondrial DNA. J. Mol. Biol. 192: 503-511.

Crowe TM, Bowie RCK, Bloomer P, Mandiwana TG, et al. (2006). Phylogenetics, biogeography and classification of, and character evolution in, gamebirds (Aves: Galliformes): effects of character exclusion, data partitioning and missing data. Cladistics 22: 495-532.

del Hoyo J, Elliot A and Sargatal J (1994). Handbook of the Birds of the World. Vol. 2. Lynx Editions, Barcelona, 434-557.

Deng WH and Zheng GM (2004). Landscape and habitat factors affecting Cabot's tragopan Tragopan caboti occurrence in habitat fragments. Biol. Conserv. 117: 25-32.

Dyke GJ, Gulas BE and Crowe TM (2003). Suprageneric relationships of galliform birds (Aves, Galliformes): a cladistic analysis of morphological characters. Zoolog. J. Linnean Soc. 137: 227-244.

Guan X, Silva P, Gyenai KB, Xu J, et al. (2009). The mitochondrial genome sequence and molecular phylogeny of the turkey, Meleagris gallopavo. Anim. Genet. 40: 134-141.

He L, Dai B, Zeng B, Zhang X, et al. (2009). The complete mitochondrial genome of the Sichuan Hill Partridge (Arborophila rufipectus) and a phylogenetic analysis with related species. Gene 435: 23-28.

IUCN (2009). IUCN Red List of Threatened Species. Gland, Switzerland. Available at [http://www.iucnredlist.org]. Accessed November 9, 2009.

Kumazawa Y and Nishida M (1993). Sequence evolution of mitochondrial tRNA genes and deep-branch animal phylogenetics. J. Mol. Evol. 37: 380-398.

L'Abbe D, Duhaime JF, Lang BF and Morais R (1991). The transcription of DNA in chicken mitochondria initiates from one major bidirectional promoter. J. Biol. Chem. 266: 10844-10850.

Larkin MA, Blackshields G, Brown NP, Chenna R, et al. (2007). Clustal W and Clustal X version 2.0. Bioinformatics 23: 2947-2948.

Lohse M, Drechsel O and Bock R (2007). Organellar Genome DRAW (OGDRAW): a tool for the easy generation of highquality custom graphical maps of plastid and mitochondrial genomes. Curr. Genet. 52: 267-274.

Lowe TM and Eddy SR (1997). tRNAscan-SE: a program for improved detection of transfer RNA genes in genomic sequence. Nucleic Acids Res. 25: 955-964.

Mindell DP, Sorenson MD and Dimcheff DE (1998). An extra nucleotide is not translated in mitochondrial ND3 of some birds and turtles. Mol. Biol. Evol. 15: 1568-1571.

Monroe BL and Sibley CG (1990). A World Checklist of Birds. Yale University Press, New Haven.

Moore WS (1995). Inferring phylogenies from mtDNA variation: mitochondrial-gene trees versus nuclear-gene trees. Evolution 49: 718-726.

Nishibori M, Hayashi T, Tsudzuki M, Yamamoto Y, et al. (2001). Complete sequence of the Japanese quail (Coturnix japonica) mitochondrial genome and its genetic relationship with related species. Anim. Genet. 32: 380-385.

Nishibori M, Tsudzuki M, Hayashi T, Yamamoto Y, et al. (2002). Complete nucleotide sequence of the Coturnix chinensis (blue-breasted quail) mitochondrial genome and a phylogenetic analysis with related species. J. Hered. 93: 439-444.

Nishibori M, Hayashi T and Yasue H (2004). Complete nucleotide sequence of Numida meleagris (Helmeted guineafowl) mitochondrial genome. J. Poult. Sci. 41: 259-268.

Nishibori M, Shimogiri T, Hayashi T and Yasue H (2005). Molecular evidence for hybridization of species in the genus Gallus except for Gallus varius. Anim. Genet. 36: 367-375.

Perna NT and Kocher TD (1995). Patterns of nucleotide composition at fourfold degenerate sites of animal mitochondrial genomes. J. Mol. Evol. 41: 353-358.

Quinn TW (1992). The genetic legacy of Mother Goose - phylogeographic patterns of lesser snow goose Chen caerulescens caerulescens maternal lineages. Mol. Ecol. 1: 105-117.

Randi E and Lucchini V (1998). Organization and evolution of the mitochondrial DNA control region in the avian genus Alectoris. J. Mol. Evol. 47: 449-462.

Ruokonen M and Kvist L (2002). Structure and evolution of the avian mitochondrial control region. Mol. Phylogenet. Evol. 23: 422-432. 
Russell RD and Beckenbach AT (2008). Recoding of translation in turtle mitochondrial genomes: programmed frameshift mutations and evidence of a modified genetic code. J. Mol. Evol. 67: 682-695.

Saccone C, Pesole G and Sbisa E (1991). The main regulatory region of mammalian mitochondrial DNA: structurefunction model and evolutionary pattern. J. Mol. Evol. 33: 83-91.

Sambrook J and Russell DW (2001). Molecular Cloning: A Laboratory Manual. 3rd edn. Cold Spring Harbor Laboratory Press, New York.

San Mauro D, Garcia-Paris M and Zardoya R (2004). Phylogenetic relationships of discoglossid frogs (Amphibia:Anura:Discoglossidae) based on complete mitochondrial genomes and nuclear genes. Gene 343: 357366.

Sbisa E, Tanzariello F, Reyes A, Pesole G, et al. (1997). Mammalian mitochondrial D-loop region structural analysis: identification of new conserved sequences and their functional and evolutionary implications. Gene 205: 125-140.

Shadel GS and Clayton DA (1997). Mitochondrial DNA maintenance in vertebrates. Annu. Rev. Biochem. 66: 409-435.

Shen X, Tian M, Liu Z, Cheng H, et al. (2009a). Complete mitochondrial genome of the sea cucumber Apostichopus japonicus (Echinodermata: Holothuroidea): the first representative from the subclass Aspidochirotacea with the echinoderm ground pattern. Gene 439: 79-86.

Shen YY, Shi P, Sun YB and Zhang YP (2009b). Relaxation of selective constraints on avian mitochondrial DNA following the degeneration of flight ability. Genome Res. 19: 1760-1765.

Slack KE, Janke A, Penny D and Arnason U (2003). Two new avian mitochondrial genomes (penguin and goose) and a summary of bird and reptile mitogenomic features. Gene 302: 43-52.

Slack KE, Delsuc F, McLenachan PA, Arnason U, et al. (2007). Resolving the root of the avian mitogenomic tree by breaking up long branches. Mol. Phylogenet. Evol. 42: 1-13.

Walberg MW and Clayton DA (1981). Sequence and properties of the human KB cell and mouse L cell D-loop regions of mitochondrial DNA. Nucleic Acids Res. 9: 5411-5421.

Wolstenholme DR (1992). Animal mitochondrial DNA: structure and evolution. Int. Rev. Cytol. 141: 173-216.

Wyman SK, Jansen RK and Boore JL (2004). Automatic annotation of organellar genomes with DOGMA. Bioinformatics 20: 3252-3255.

Zhang JF, Nie LW, Wang Y and Hu LL (2009). The complete mitochondrial genome of the large-headed frog, Limnonectes bannaensis (Amphibia: Anura), and a novel gene organization in the vertebrate mtDNA. Gene 442: 119-127.

Zhang Y and Zheng G (2007). A population viability analysis (PVA) for Cabot's tragopan (Tragopan caboti) in Wuyanling, south-east China. Bird Conserv. Int. 17: 151-161. 